\title{
Flavanol derivatives with antioxidant activity from the stem bark of Xylocarpus granatum
}

\author{
Musa CHACHA \\ Institute of Marine Sciences, University of Dar es Salaam, P. O. Box 668, Zanzibar, Tanzania. \\ Email address: chacha@ims.udsm.ac.tz.
}

\begin{abstract}
A new flavanol derivative dihydrocaffeic acid- $(3 \rightarrow 8)$-epicatechin together with two known derivatives, $(+)$-catechin and catechin- $(4 \beta \rightarrow 8)$-catechin were isolated from the stem bark of a mangrove plant Xylocarpus granatum. Their structures were established using 1D and 2D NMR experiments as well as HRMS-FAB, EIMS, IR and UV spectra. The compounds were evaluated for DPPH radical scavenging activity and ferric reducing antioxidant power and they exhibited higher activity compared to butylated hydroxytoluene (BHT) which is a commercially available antioxidant. Catechin- $(4 \beta \rightarrow 8)$-catechin showed the highest DPPH radical scavenging activity with $\mathrm{IC}_{50}$ of $4.5 \mu \mathrm{g} / \mathrm{mL}$.
\end{abstract}

(C) 2010 International Formulae Group. All rights reserved.

Keywords: Xylocarpus granatum, flavanol derivative, antioxidant activity.

\section{INTRODUCTION}

The genus Xylocarpus (Meliaceae) comprises of three mangrove plant species, Xylocarpus granatum J. König, Xylocarpus mekongenesis Pierre and Xylocarpus moluccensis Lamk M. Roem (Alvi et al., 1991). The three species are widely distributed along the sea coasts of Africa, South Asia and South Pacific islands (Tomlinson, 1986). Xylocarpus granatum is a moderate sized evergreen tree with grey barks and has for many years being used by mangrove dwellers for the treatment of swelling of breast, elephantiasis, dysentery, diarrhea and other abdominal troubles (Ghani, 1998; Rouf et al., 2007). Previous phytochemical investigations of the stem bark and seeds of $X$. granatum afforded a number of alkaloids (Chou et al., 1977) and limonoids (Cui et al., 2005; Alvi et al., 1991; Connolly et al., 1977; Kokpol et al., 1996; NgAng and Fallis, 1979; Wu et al., 2004a,b; 2005a,b; 2006a,b). In this study, the stem bark of Xylocarpus granatum was investigated and a new flavanol derivative, dihydrocaffeic acid$(3 \rightarrow 8)$-epicatechin $(2)$ along with two known flavanol derivatives (+)-catechin (1) and catechin- $(4 \beta \rightarrow 8)$-catechin $(\mathbf{3})$ were isolated.

\section{MATERIALS AND METHODS}

General experimental procedures

The ultraviolet and visible (UV-VIS) spectra were taken on Shimadzu UV-2101PC UV-Vis Scanning Spectrophotometer. Infra Red spectra were recorded on Perkin-Elmer 2000 FT-IR spectrometer using $\mathrm{KBr}$ pellets. 
${ }^{1} \mathrm{H}$ NMR, ${ }^{13} \mathrm{C}$ NMR, DEPT, COSY, HMQC and HMBC were acquired on Bruker Avance DPX 300 spectrometer using standard pulse sequences and referenced to residual solvent signal. Low-resolution mass spectra were obtained on Finnigan MAT $\mathrm{LCQ}^{\mathrm{DECA}}$ instrument and high resolution mass spectra were obtained on GCT Premier Instrument. Specific rotations $[\alpha]_{D}$ were measured on a polatronic-D $\quad$ (Schmidt + Haensch) polarimeter. Analytical thin layer chromatograms were run on readymade 0.25 $\mathrm{mm}$ thick layer of Merck silica gel $60 \mathrm{~F}_{254+366}$ coated on aluminium foil. Spots on the chromatograms were detected by observing in UV light (254 and $366 \mathrm{~nm}$ ) and sprayed with vanillin-sulphuric acid reagent. Preparative thin layer chromatograms were run on $0.5 \mathrm{~mm}$ thick layer silica gel $60 \mathrm{HF}_{254+366}$ containing $\mathrm{CaSO}_{4}$ (binder) coated on $20 \times 20 \mathrm{~cm}$ glass plates. Chromatographic separations were achieved using different sizes of columns packed with silica gel $60(0.0400-0.0630 \mathrm{~mm})$ and Sephadex LH-20.

\section{Plant materials}

Stem bark of Xylocarpus granatum was collected in September 2008 at Kisakasaka Mangrove Reserve, Zanzibar, Tanzania. A voucher specimen (MC XG4) has been deposited in the Institute of Marine Sciences, Zanzibar.

\section{Extraction and isolation}

The pulverized stem bark of Xylocarpus granatum $(230 \mathrm{~g})$ was extracted with a mixture of $\mathrm{CHCl}_{3} / \mathrm{MeOH}(1: 1)$ at room temperature for twenty four hours. The obtained extract was concentrated and yielded a residue (46 g) which was adsorbed on silica gel $(50 \mathrm{~g})$ and applied to a column packed with silica gel $(1100$ g) using $n$ hexane/EtOAc/acetone (3:3:1). The column was eluted using the same solvent system and the following combined fractions were collected: A (1-9), B (10-11) and C (12-14). The combined fraction A $(5.4 \mathrm{~g})$ was passed through column chromatography using Sephadex® LH 20 eluted with $\mathrm{CHCl}_{3} / \mathrm{MeOH}$ as an eluent to afford (+)-catechin (23.8 mg).
The combined fractions C $(15.9 \mathrm{~g})$ was adsorbed on silica gel $(16 \mathrm{~g})$ and loaded on a silica gel column packed and eluted with $n$ hexane/EtOAc/acetone $(1.5: 1.5: 1.0)$ to give subfractions $\mathrm{C} 1$ and $\mathrm{C} 2$. Subfraction $\mathrm{C} 1$ was passed through column chromatography using Sephadex ${ }^{\circledR}$ LH 20 packed and eluted with $\mathrm{CHCl}_{3} / \mathrm{MeOH}$ (1:1) to obtain $\mathrm{C} 1.1$ which was applied on a preparative thin layer chromatography eluted with $n$ hexane/acetone/acetic acid (6:5:3 drops) to obtain a brown paste which was identified as dihydrocaffeic acid-( $3 \rightarrow 8)$-epicatechin (30.0 $\mathrm{mg}$ ). Subfraction $\mathrm{C} 2$ was adsorbed on $5 \mathrm{~g}$ of silica gel and applied to a silica gel column eluted with $n$-hexane/EtOAc/acetone/HOAc $(3: 3: 3: 1)$ to give catechin- $(4 \beta \rightarrow 8)$-catechin (16.8 mg).

Dihydrocaffeic acid-(3 $\rightarrow$ 8)-epicatechin (2). Brown paste; $[\alpha]_{\mathrm{D}}$ : $-45.6^{\circ}$ (c 2.00, $\mathrm{MeOH}$ ); Rf : 0.5 (Hexane-Acetone-Acetic acid, 6:5:3 drops); IR (KBr): 3402, 1720, $1648,1518,1459 \mathrm{~cm}^{-1}$; UV/Vis $\lambda_{\max }(\mathrm{MeOH})$ nm (log $\varepsilon): 262$ (3.62), 285 (2.90); ${ }^{1} \mathrm{H}$ NMR and ${ }^{13} \mathrm{C}$ NMR see Table 1; MS (EI, $70 \mathrm{eV}$ ): $\mathrm{m} / \mathrm{z}(\%)=471\left[\mathrm{M}+\mathrm{H}^{+}\right](67), 343(100), 427$ (70); HRMS-FAB: $\mathrm{m} / z \quad\left[\mathrm{M}^{+}\right]$calcd for $\mathrm{C}_{24} \mathrm{H}_{22} \mathrm{O}_{10}$ : 470.42548 ; found: 470.42543 .

The DPPH (1,1-diphenyl-2-picryl-hydrazyl) radical scavenging activities

The scavenging effects of isolated compounds on DPPH radical were determined according to the method described by Duan et al. (2006).

\section{Ferric-reducing antioxidant method}

The reduction capacity of the compounds 1, 2 and $\mathbf{3}$ was determined according to the method described by Oyaizu (1986) which is based on $\mathrm{Fe}^{3+} \rightarrow \mathrm{Fe}^{2+}$. The absorbance of the reaction mixture was read at $700 \mathrm{~nm}$ and increase in absorbance indicated the reducing power of a compound.

\section{RESULTS AND DISCUSSION}

The pulverized stem bark of Xylocarpus granatum was subjected to chromatographic and gel filtration techniques 
to give three flavanol derivatives (Figure 1) of which dihydrocaffeic acid- $(3 \rightarrow 8)$-epicatechin (2) is reported for the first time in nature. Catechin (1) is widely distributed in the plant kingdom and has been shown to be beneficial to human health whereas catechin- $(4 \beta \rightarrow 8)$ catechin (3) was reported as the first natural procyanidin with a 3,4-cis configuration from Potentilla erecta (Scleep et al., 1986). However, it is reported for the first time from the genus Xylocarpus.

Compound 2 was isolated as a brown paste and was observed as a red spot on thin layer chromatography following vanillinsulphuric acid spray. Its HREIMS spectrum showed a molecular ion peak at $\mathrm{m} / \mathrm{z}$ $470.42543[\mathrm{M}]^{+}$consistent with a molecular formula $\mathrm{C}_{24} \mathrm{H}_{22} \mathrm{O}_{10}$. The IR absorptions at $3402,1720,1648 \mathrm{~cm}^{-1}$ suggested the presence of $\mathrm{O}-\mathrm{H}, \mathrm{C}=\mathrm{O}$ and $\mathrm{C}=\mathrm{C}$ stretches respectively. The ${ }^{1} \mathrm{H}$ NMR spectrum and ${ }^{1} \mathrm{H}-{ }^{1} \mathrm{H}$ COSY correlation revealed the presence of proton signals attributed to the $\mathrm{C}$-ring of epicatechin at $\delta_{\mathrm{H}} 4.89(1 \mathrm{H}, b r s, \mathrm{H}-2), \delta_{\mathrm{H}} 4.28(1 \mathrm{H}, m, \mathrm{H}-$ 3), $\delta_{\mathrm{H}} 2.91(1 \mathrm{H}, d d, J=16.5,4.5 \mathrm{~Hz}, \mathrm{H}-4 \mathrm{a})$ and $\delta_{\mathrm{H}} 2.82(1 \mathrm{H}, d d, J=16.5,3.0 \mathrm{~Hz}, \mathrm{H}-4 \mathrm{~b})$ (Agrawal et al., 1989). The ${ }^{1} \mathrm{H}$ NMR and ${ }^{1} \mathrm{H}$ ${ }^{1} \mathrm{H}$ COSY correlation further revealed the presence of three aromatic protons at $\delta_{\mathrm{H}} 7.04$ $(1 \mathrm{H}, d, J=1.5 \mathrm{~Hz}), \delta_{\mathrm{H}} 6.81(1 \mathrm{H}, d d, J=8.1$, $1.8 \mathrm{~Hz})$ and $\delta_{\mathrm{H}} 6.77(1 \mathrm{H}, d, J=8.1 \mathrm{~Hz})$ which on the basis of HMQC and HMBC spectral data were assigned to $\mathrm{H}-2^{\prime}, \mathrm{H}-6^{\prime}$ and $\mathrm{H}-5^{\prime}$ respectively (Table 1 ). A sharp singlet signal at $\delta_{\mathrm{H}} 6.23$ was evident in the ${ }^{1} \mathrm{H}$ NMR and was assigned to H-6 based on the HMQC and HMBC spectral data. The absence of a proton signal due to $\mathrm{H}-8$ in the ${ }^{1} \mathrm{H}$ NMR spectrum suggested the presence of another group linked to epicatechin at $\mathrm{C}-8$. In addition to signals attributed to epicatechin skeleton, ${ }^{1} \mathrm{H}$ NMR spectrum exhibited the signals for a dihydrocaffeic acid moiety [at $\delta_{\mathrm{H}} 3.09(1 \mathrm{H}$, $d d, J=16.6,6.9 \mathrm{~Hz}, \mathrm{H}-2 \mathrm{a} "), \delta_{\mathrm{H}} 2.93(1 \mathrm{H}, d d$, $\left.J=16.6,2.1 \mathrm{~Hz}, \mathrm{H}-2 \mathrm{~b}^{\prime}\right), \delta_{\mathrm{H}} 4.55$ (dd, $J=6.9$, $2.1 \mathrm{~Hz}, \mathrm{H}-3 "), \delta_{\mathrm{H}} 6.58(1 \mathrm{H}, d, J=2.1 \mathrm{~Hz}, \mathrm{H}-$ $\left.5^{\prime \prime}\right), \delta_{\mathrm{H}} 6.64\left(1 \mathrm{H}, d, J=8.1 \mathrm{~Hz}, \mathrm{H}-8^{\prime \prime}\right)$ and $\delta_{\mathrm{H}}$ $6.48(1 \mathrm{H}, d d, J=8.1,2.1 \mathrm{~Hz}, \mathrm{H}-9 ")]$. The connection of dihydrocaffeic acid moiety to epicatechin skeleton was confirmed through close examination of HMBC correlations of H-6 $\left(\delta_{\mathrm{H}} 6.23\right), \mathrm{H}-3 "\left(\delta_{\mathrm{H}} 4.55\right)$ and methylene protons $\mathrm{H}-2$ " $\left(\delta_{\mathrm{H}} 3.09\right.$ and $\left.\delta_{\mathrm{H}} 2.93\right)$. They both showed HMBC correlation with a quaternary carbon at $\delta_{\mathrm{C}} 104.7(s, \mathrm{C}-8)$. In addition, a proton assigned to H-3" showed HMBC correlations to carbons originating from dihydrocaffeic acid moiety [C-1" ( $\left.\delta_{\mathrm{C}} 168.3\right)$, C-2" $\left(\delta_{\mathrm{C}} 38.1\right), \mathrm{C}-5 "\left(\delta_{\mathrm{C}} 114.8\right)$ and C-9" $\left(\delta_{\mathrm{C}}\right.$ $119.0)]$ and epicatechin skeleton $\left[\mathrm{C}-7 \quad\left(\delta_{\mathrm{C}}\right.\right.$ $151.7), \mathrm{C}-8\left(\delta_{\mathrm{C}} 104.7\right)$ and $\left.\mathrm{C}-9\left(\delta_{\mathrm{C}} 156.6\right)\right]$ as shown in Figure 2. Compound 2 was thus identified as dihydrocaffeic acid- $(3 \rightarrow 8)$ epicatechin and to the best of my knowledge; this is the first report of compound $\mathbf{2}$ from nature.

The DPPH radical scavenging activity of (+)-catechin (1), dihydrocaffeic acid$(3 \rightarrow 8)$-epicatechin $(2)$ and catechin- $(4 \beta \rightarrow 8)$ catechin (3) is presented in Table 2. All compounds displayed higher DPPH radical scavenging activity compared to butylated hydroxytoluene (BHT) which is a commercially available antioxidant. Compound $\mathbf{3}$ showed the strongest activity with $\mathrm{IC}_{50} 4.5 \mu \mathrm{g} / \mathrm{mL}$ which was four times more active than BHT $\left(\mathrm{IC}_{50} 18.2 \mu \mathrm{g} / \mathrm{mL}\right)$. The DPPH radical scavenging activities of these compounds seemed to be related to the number of hydroxyl groups which agrees with reported structure-activity relationships for flavonoids (Chacha et al., 2005).

In the Ferric-reducing antioxidant potential (FRAP) assay, compounds 1-3 reduced $\mathrm{Fe}^{3+}$ to $\mathrm{Fe}^{2+}$ and the formation of $\mathrm{Fe}^{2+}$ was monitored by measuring the formation of Perl's Prussian blue at $700 \mathrm{~nm}$. Increase in absorbance indicated an increase in reducing power. Table 3 shows the reducing power of compounds 1-3 and BHT. All tested compounds exhibited higher reducing power compared to BHT. Catechin- $(4 \beta \rightarrow 8)$-catechin (3) was the most active which suggested that reducing power of flavonol derivatives depends on the number of the hydroxyl groups. 

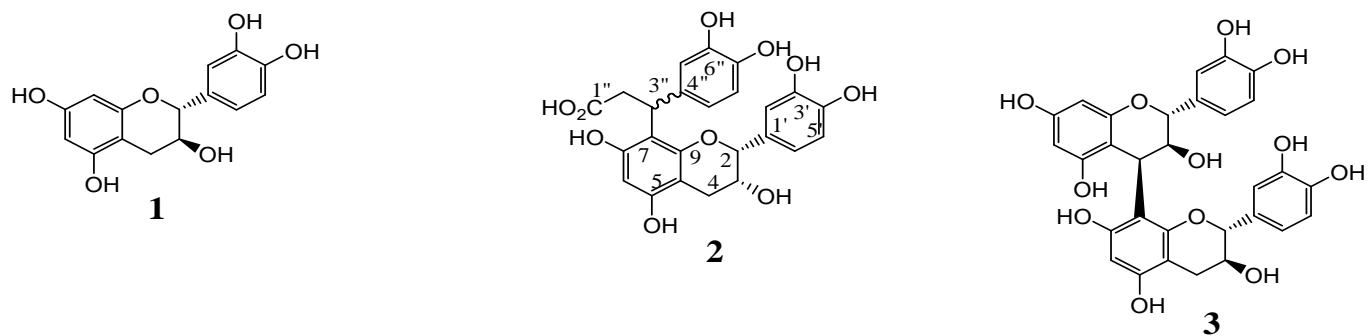

Figure 1: Structures of compounds $\mathbf{1}, \mathbf{2}$ and $\mathbf{3}$.

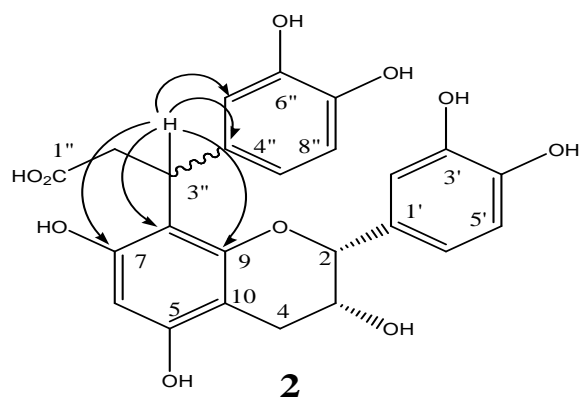

Figure 2: HMBC correlations of $\mathrm{H}-2 "$.

Table 1: ${ }^{1} \mathrm{H}$ - and ${ }^{13} \mathrm{C}-\mathrm{NMR}$ data of $2\left[(\mathrm{CD})_{2} \mathrm{CO}, 300 / 150 \mathrm{MHZ}, J \text { in } \mathrm{Hz}, \delta \text { in ppm) }\right)^{\mathrm{a}}$.

\begin{tabular}{llllll}
\hline $\mathbf{C}$ & $\boldsymbol{\delta}_{\mathbf{H}}$ & $\boldsymbol{\delta}_{\mathbf{C}}$ & $\mathbf{C}$ & $\boldsymbol{\delta}_{\mathbf{H}}$ & $\boldsymbol{\delta}_{\mathbf{C}}$ \\
\hline 2 & $4.89 b r s$ & $79.3(d)$ & $4^{\prime}$ & & $145.2(s)$ \\
3 & $4.28 m$ & $66.1(d)$ & $5^{\prime}$ & $6.77, d(8.1)$ & $115.6(d)$ \\
$4 \mathrm{a}$ & $2.91 d d(16.5,4.5)$ & $29.8(t)$ & $6^{\prime}$ & $6.81, d d(8.1,1.8)$ & $118.7(d)$ \\
$4 \mathrm{~b}$ & $2.82, d d(16.5,3.0)$ & $29.8(t)$ & $1^{\prime \prime}$ & & $168.3(s)$ \\
5 & & $153.0(s)$ & $2 \mathrm{a}^{\prime \prime}$ & $3.09, d d(16.6,6.9)$ & $38.1(t)$ \\
6 & $6.23, s$ & $96.1(d)$ & $2 \mathrm{~b}^{\prime \prime}$ & $2.93, d d(16.6,2.1)$ & $38.1(t)$ \\
7 & & $151.7(s)$ & $3^{\prime \prime}$ & $4.55, d d(7.2,2.1)$ & $34.8(d)$ \\
8 & & $104.7(s)$ & $4^{\prime \prime}$ & & $135.2(s)$ \\
9 & & $156.6(s)$ & $5^{\prime \prime}$ & $6.58, d(2.1)$ & $114.8(d)$ \\
10 & & $105.7(s)$ & $6^{\prime \prime}$ & & $144.7(s)$ \\
$1^{\prime}$ & & $131.8(s)$ & $7^{\prime \prime}$ & & $145.4(s)$ \\
$2^{\prime}$ & $7.04, d(1.5)$ & $114.7(d)$ & $8^{\prime \prime}$ & $6.64, d(8.1)$ & $116.1(d)$ \\
$3^{\prime}$ & & $145.8(s)$ & $9^{\prime \prime}$ & $6.48, d d(8.1,1.8)$ & $119.0(d)$ \\
\hline${ }^{a}$ Assignm $(d)$
\end{tabular}

${ }^{\mathrm{a}}$ Assignments are based on DEPT, HMQC and HMBC experiments.

Table 2: The $\mathrm{IC}_{50}(\mu \mathrm{g} / \mathrm{mL})$ of compounds 1-3 and BHT in DPPH radical scavenging assay.

\begin{tabular}{|c|c|}
\hline Compounds & $\mathrm{IC}_{50}(\mu \mathrm{g} / \mathrm{mL})$ \\
\hline$(+)$-Catechin (1) & 6.6 \\
\hline Dihydrocaffeic acid-(3 $\rightarrow$ 8)-epicatechin $(2)$ & 7.9 \\
\hline Catechin- $(4 \beta \rightarrow 8)$-catechin $(3)$ & 4.5 \\
\hline Butylated hydroxytoluene (BHT) & 18.2 \\
\hline
\end{tabular}


Table 3: Absorbance of compounds 1-3 and BHT in ferric-reducing antioxidant potential (FRAP)

\begin{tabular}{lc}
\hline Compounds & Absorbance at $\mathbf{7 0 0} \mathbf{~ n m}$ \\
\hline (+)-Catechin $(\mathbf{1})$ & 0.6 \\
Dihydrocaffeic acid- $(3 \rightarrow 8)$-epicatechin $(\mathbf{2})$ & 0.65 \\
Catechin- $(4 \beta \rightarrow 8)$-catechin $(\mathbf{3})$ & 0.82 \\
Butylated hydroxytoluene (BHT) & 0.14 \\
\hline
\end{tabular}

\section{ACKNOWLEDGMENTS}

This work was financially supported by the Western Indian Ocean Marine Science Association (WIOMSA)-MARG I Grant, Contracted Number: 14/2008.

\section{REFERENCES}

Alvi KA, Crews P, Aalbersberg B, Prasad R. 1991. Limonoids from the Fijian medicinal plant Dabi (Xylocarpus). Tetrahedron, 47(43): 8943-8948.

Agrawal PK, Bansal MC, Porter LJ, Foo LP. 1989. Flavonoids. In Carbon-13 NMR of Flavonoids, Agrawal PK (ed). Elsevier: New York; 431-496.

Chacha M, Bojase-Moleta G, Majinda RRT. 2005. Antimicrobial and radical scavenging flavonoids from the stem wood of Erythrina latissima. Phytochemistry, 66(1): 99-104.

Chou FY, Hostettman K, Kubo I, Nakanishi K, Taniguchi M. 1977. Isolation of an insect antifeedant N-Methylflindersine and several benz $(\mathrm{C})$ Phenanthridine alkaloids from East African plants; a comment on chelerythrine. Heterocycles, 88(7): 967-977.

Connolly JD, Maclellan M, Okorie DA, Taylor DAH. 1976. Limonoids from Xylocarpus moluccensis (Lam). J. Chem. Soc., 1: 1093-1096.

Cui J, Deng Z, Li J, Fu H, Proksch P, Lin W. 2005. Phragmalin-type limonoids from the marine mangrove plant Xylocarpus granatum. Phytochemistry, 66(19): 23342339.

Duan S, Weng XC, Dung XW. 1998. Antioxidant properties of butylated hydroxytoluene refluxed in ferric chloride solution. Food Chemistry, 61(1): 101-105.

Ghani A. 1998. Medicinal plant of Bangladesh with chemical constituents and uses. Asiatic society of Bangladesh.

Kokpol U, Chavasiri WRN, Tip PS, Verachato G, Zhao F, Simpson J, Weavers RT. 1996. A limonoid from Xylocarpus granatum. Phytochemistry, 41(3): 903-905.

NgAng S, Fallis AG. 1979. 7aacetoxydihydronomillin and mexicanolide: limonoids from Xylocarpus granatum (Koenig). J. Chem. Soc., 57(x): 3088-3089.

Oyaizu M. 1986. Studies on product of browning reaction prepared from glucose amine. Jpn. J. Nutr., 44(25): 307-315.

Rouf R, Uddin SJ, Shilpi JA, Alamgir M. 2007. Assessment of antidiarrheal activity of the methanol extract of Xylocarpus granatum bark in mice model. $J$. Ethnopharmacol. 109(3): $\quad$ 539-542.

Schleep S, friedrich H, Kolodziej H. 1986. The natural procyanidin with a 3,4-cis configuration. J. Chem. Soc., 5: 392-393.

Tomlinson PB. 1986. The Botany of Mangroves. Cambridge University Press: Cambridge.

Wu J, Zhang S, Xiao Q, Li Q, Huang J, Long L, Huang L. 2004a. Xyloccensin L, a novel limonoid from Xylocarpus granatum. Tetrahedron Letters, 45(3): 591-593.

Wu J, Xiao Q, Huang J, Xiao Z, Qi Q, Zhang S. 2004b. Xyloccensins $\mathrm{O}$ and $\mathrm{P}$, unique 
8,9,30-phragmalin ortho esters from Xylocarpus granatum. Org. Lett., 6(11): 1841-1844.

Wu J, Xiao Q, Zhang S, Li X, Xiao Z, Ding H, Li Q. 2005a. Xyloccensins Q-V, six new 8,9,30-phragmalin ortho ester antifeedants from the Chinese mangrove Xylocarpus granatum. Tetrahedron, 61(35): 8382-8389.

Wu J, Zhang S, Song Y, Xiao Z, Xiao Q, Li Q. 2005b. Two new mexicanolides from the fruits of the Chinese mangrove Xylocarpus granatum. Zeitschrift für Naturforschung, 60b: 1-4.
Wu J, Xiao Q, Li Q. 2006a. Limonoids from the mangrove Xylocarpus granatum. Biochem. Syst. Ecol., 34(11): 838-841.

Wu J, Xiao Z, Song Y, Zhang S, Xiao Q, Ma C, Ding H, Li Q. 2006b. Spectral assignments and reference data: complete assignments of ${ }^{1} \mathrm{H}$ and ${ }^{13} \mathrm{C}$ NMR data for two $3 \beta, 8 \beta$-epoxymexicanolides from the fruit of a Chinese mangrove Xylocarpus granatum. Magn. Reson. Chem., 44(1): 87-89. 